NBER WORKING PAPER SERIES

\title{
WHEN IN PERIL, RETRENCH: TESTING THE PORTFOLIO CHANNEL OF CONTAGION
}

\author{
Fernando A. Broner \\ R. Gaston Gelos \\ Carmen M. Reinhart \\ Working Paper 10941 \\ http://www.nber.org/papers/w10941
NATIONAL BUREAU OF ECONOMIC RESEARCH
1050 Massachusetts Avenue
Cambridge, MA 02138 \\ December 2004
}

The views expressed in this paper are those of the authors and do not necessarily represent those of the IMF or IMF policy. The authors are grateful to Guillermo Vuletin for able research assistance and to PierreOlivier Gourinchas, Alejandro Justiniano, Laura Kodres, Miguel Messmacher, Paolo Pesenti, Raghuram Rajan, Juan Solé, Jeremy Stein, and seminar participants at the Bank of Spain, the AEA Annual Meetings (San Diego), the Fourth Annual IMF Research Conference, and the FRBSF and University of Maryland Emerging Markets Conference for helpful comments. The views expressed herein are those of the author(s) and do not necessarily reflect the views of the National Bureau of Economic Research.

(C) 2004 by Fernando A. Broner, R. Gaston Gelos, and Carmen M. Reinhart. All rights reserved. Short sections of text, not to exceed two paragraphs, may be quoted without explicit permission provided that full credit, including () notice, is given to the source. 
When in Peril, Retrench: Testing the Portfolio Channel of Contagion

Fernando A. Broner, R. Gaston Gelos, and Carmen M. Reinhart

NBER Working Paper No. 10941

December 2004

JEL No. F02, F30, F32, F36

\section{ABSTRACT}

One plausible mechanism through which financial market shocks may propagate across countries is through the effect of past gains and losses on investors' risk aversion. The paper first presents a simple model examining how heterogeneous changes in investors' risk aversion affects portfolio decisions and stock prices. Second, the paper shows empirically that, when funds' returns are below average, they adjust their holdings toward the average (or benchmark) portfolio. In other words, they tend to sell the assets of countries in which they were "overweight", increasing their exposure to countries in which they were "underweight." Based on this insight, the paper discusses a matrix of financial interdependence reflecting the extent to which countries share overexposed funds. Comparing this measure to indices of trade or bank linkages indicates that our index can improve predictions about which countries are likely to be affected by contagion from crisis centers.

Fernando A. Broner

CREI

Universitat Pompeu Fabra

Ramon Trias Frgas, 25-27

08005 Barcelona, Spain

R. Gaston Gelos

International Monetary Fund

Washington, DC

ggelos@imf.org

Carmen Reinhart

University of Maryland

School of Public Affairs and Department of Economics

4105 Van Munching Hall

College Park, Maryland 20742 


\section{Introduction}

How do financial crises spread across countries? As a result of the large number of currency and banking crises observed over the last decade, substantial research effort has been devoted to answering this question. A growing consensus has emerged that financial linkages and frictions are likely to play a significant role in the propagation of shocks across countries.

At a theoretical level, various authors have sought to explain international financial contagion effects with models of investor portfolio choice. Schinasi and Smith (2000) highlight that contagion effects can be the result of simple portfolio rebalancing within a mean-variance or VaR framework. In Kodres and Pritsker (2002), differentially informed investors transmit idiosyncratic shocks from one market to others by rebalancing their portfolios' exposures to common macroeconomic risks. Kyle and Xiong (2001) model contagion as a wealth effect in a model with two risky assets and different types of traders. Wealth effects as a source of contagion also figure prominently in the models of Goldstein and Pauzner (2001) and Yuan (2004). In a different approach, Calvo and Mendoza (2000) describe fund managers' investment decisions using a mean-variance framework with short-selling constraints, including fixed costs of information acquisition about countries and assuming that fund managers' performance schemes create incentives against deviating too much from benchmark indices.

Empirically, there are also some indications that financial links matter. Kaminsky and Reinhart (2000), Hernández and Valdés (2001), Van Rijckeghem and Weder (2001), and Caramazza, Ricci, and Salgado (2000) provide evidence that if two countries borrow from banks located in a common third country, crises are transmitted more easily. However, they do not directly identify the particular mechanism accounting for this phenomenon. Providing empirical support for Calvo's and Mendoza's model, Disyatat and Gelos (2001) show that emerging market funds' asset allocation can be well approximated by model with short-sale constraints and mean-variance optimization around benchmark indices. Van Rijckeghem and Weder (2003) provide evidence that bank exposures to crisis countries can help predict flows to third countries after the Mexican and Asian crises. None of these studies, however, has used cross-sectional information in portfolio positions at the micro level to identify the exact nature of financial linkages. For example, the studies stressing common lender effects through banks are based on aggregate information on bank positions, as reported by the BIS. ${ }^{1}$

\footnotetext{
${ }^{1}$ See Kaminsky, Reinhart, and Vegh (2003) for a recent discussion of the evidence on contagion.
} 
In this paper, we study the trading behavior of emerging market mutual funds and its role in the transmission of shocks across countries. We take advantage of a large database of emerging market funds that contains disaggregated information on the investments of hundreds of funds. For each fund, the database contains monthly data on its asset allocation by country for the period January 1996 through December 2000. This detailed information allows us to characterize the behavior of international investors to a greater extent than was possible in previous studies. Although we focus on a particular type of investor, their behavior is likely representative of other types of investors as well. Importantly, the portfolio allocation of mutual funds is heterogeneous. This heterogeneity implies not only that funds are affected to different extents during crises, but also that the resulting portfolio reallocations transmit the crisis to some countries more than others.

We present a simple model that analyzes the effect of changes in investors' risk aversion on portfolio decisions and stock prices. The model incorporates three main ingredients: (i) investors hold heterogeneous portfolios and may differ in their levels of risk aversion, (ii) changes in an investor's level of risk aversion affect his portfolio decisions, and (iii) portfolio decisions affect stock prices. The model shows that, if an investor cares about his performance relative to that of other investors, in response to an increase in risk aversion he would shift his portfolio towards the average portfolio. Namely, he would sell assets of countries to which he is "overexposed," and buy assets of countries to which he is "underexposed." The model also shows how crises may be transmitted through the interaction of risk aversion and heterogeneous portfolios. Since crises affect most those investors who are most exposed to the crisis country and those investors, in turn, adjust their portfolios away from other countries in which they are overexposed, crises are transmitted through common overexposed investors. $^{2}$

In the empirical analysis, we first examine the effect of gains and losses on investors' portfolios. Consistent with the model, we find that when the returns of a fund are low relative to the returns of other funds, it tends to reduce its weight in countries in which it was overexposed and increase its weight in countries in which it was underexposed, thereby adjusting its portfolio in the direction of the average portfolio. We interpret these results as suggesting that past performance has an effect on funds

\footnotetext{
${ }^{2}$ In the model, investors care about both absolute returns and returns in excess of those of other investors. The model is related to, but simpler than, models in which investors' utility is a decreasing function of the variance of their excess returns over that of other investors (tracking error variance). See Disyatat and Gelos (2001).
} 
risk aversion, and that changes in risk aversion affect fund portfolios in the direction predicted by the model. $^{3,4}$

Next, we construct a time-varying matrix of financial interdependence, based on the extent to which countries share overexposed funds. We examine whether during the Thai, Russian, and Brazilian crises, our measure of financial interdependence helps explain the degree to which stock markets fell across the world. There is a negative correlation between countries' stock market performance during these crises and the degree to which these countries shared overexposed funds with the crisis country. The effect of financial interdependence index remains significant in various cases even after controlling for trade or bank linkages. This suggests that policymakers could benefit from closely monitoring the micro composition of investments across funds in order to predict and possibly avert contagion effects.

These findings may also have interesting implications for understanding momentum trading at the country level. The fact that, in response to below-average overall performance, funds tend to reduce their investments in countries in which they are overexposed can account for the observation that, in the aggregate, funds reduce their investments in countries in which returns are low (positive-feedback trading). ${ }^{5}$ The reason is that when returns in a country are low, funds that are overexposed to that country tend to have below-average gains. As a result, they reduce their exposure to all countries in which they are overexposed, including the affected country. Likewise, the funds whose gains are above average further reduce their exposure to countries in which they are underexposed, including the affected country. Both effects lead to positive feedback trading in the aggregate.

\section{Model}

In this section, we present a stylized model to help in the interpretation of our empirical results on fund behavior and the transmission of crises. We present a simple model that incorporates the main

\footnotetext{
${ }^{3}$ Such changes in risk aversion may result from a wealth effect or be due to compensation schemes for managers that strongly penalize losses in excess of the industry average, such as hypothesized in Calvo and Mendoza (2000). There is a substantial literature examining the risk-taking behavior of domestic U.S. fund managers in response to prior performance (see Chevalier and Ellison, 1996, Brown, Harlow, and Starks, 1996, and Daniel and Wermers, 2000, among many others). Although this is not the focus of our paper, a discussion of these issues is provided in Appendix I. More generally, changes in risk aversion by investors have occasionally been cited as a possible source of contagion. See, for example, Kumar and Persaud (2001).

${ }^{4}$ Broner, Lorenzoni, and Schmukler (2003) show that the behavior of the term structure of emerging market sovereign bonds suggests that investors' risk aversion increases during crises.

5 Among others, Borensztein and Gelos (2003a), Kaminsky, Lyons, and Schmukler (2000), and Froot, O'Connell, and Seasholes (2001) present evidence of positive feedback trading in emerging markets.
} 
ingredients of our story: investors hold heterogeneous portfolios and may differ in their levels of risk aversion, changes in an investor's level of risk aversion affect his portfolio decisions, and portfolio decisions affect stock prices. ${ }^{6}$

We assume that investors hold different portfolios because they have different beliefs about expected dividends. Investors agree to disagree, in the sense that they choose to ignore the beliefs of other investors even though these may be reflected in prices. ${ }^{7}$ We also assume that investors are risk averse and may differ in their levels of risk aversion. ${ }^{8}$ The existence of heterogeneity across these two dimensions, beliefs and risk aversion, are necessary to show how a change in an investor's risk aversion affects his portfolio decisions. The mechanism works through the interaction of risk aversion and beliefs: we show that an increase in an investor's risk aversion leads to a desire to shift his portfolio away from countries about which he is relatively optimistic, and towards those about which he is relatively pessimistic. ${ }^{9}$

However, the effect of demand shifts on actual portfolio adjustments and asset prices depend on the supply of assets faced by investors. We consider two polar cases. At one extreme, we consider the case in which the supply of assets is completely inelastic. In this case, the price of the assets adjusts so that, in equilibrium, total asset demand equals the fixed asset supply. At the other extreme, we consider the case in which the supply of assets is completely elastic. In this case, the quantities of assets adjust so that in equilibrium their prices are constant.

Which assumption is more plausible empirically? In the empirical section, we will be using monthly data and focusing on relatively high frequency effects, and this may suggest that it is more reasonable to assume that the supply of assets be quite inelastic. On the other hand, the effective supply of assets faced by global mutual funds may be increasing in the price they are willing to pay both because the actual supply of assets may be somewhat elastic even in the short run, and also because the

\footnotetext{
${ }^{6}$ Providing a fully-fledged theoretical analysis is outside the scope of this paper and, as a result, we leave out some relevant ingredients. In particular, we take risk aversion levels as exogenous parameters, and analyze the effect of changes in risk aversion by performing comparative statics on these parameters.

${ }^{7}$ There exist several models of asset pricing in which investors agree to disagree, especially in the bubbles literature. See for example Harrison and Kreps (1978), Scheinkman and Xiong (2003), and Hong and Stein (2003). There may be other reasons why investors hold different portfolios. For example, countries may differ in the volatility of dividends, or the correlation between a country's dividends and investors' marginal utility may be different for different investors. We chose to assume differences in beliefs for simplicity.

${ }^{8}$ To be able to solve the model analytically, we consider the case of CARA preferences and normally distributed dividends, as in Calvo and Mendoza (1999), Kodres and Prisker (2002), and Yuan (2004).

${ }^{9} \mathrm{We}$ assume that there exists heterogeneity in investors' beliefs and risk aversion, but investors are otherwise similar. Other papers assume the existence of different classes of investors, but homogeneity within each class. For example, Kodres and Prisker (2002) assume the existence of informed investors, uninformed investors, and noise traders, while Kyle and Xiong (2001) assume the existence of long-term value-based investors, convergence traders, and noise traders.
} 
demand by other investors not captured in the model may be somewhat elastic. ${ }^{10}$ While the model is a general equilibrium one, in the empirical section we will focus on a particular class of foreign investors, neglecting the role of other, in particular, domestic agents. In that context, assuming an elastic supply curve could justified as a shortcut to introduce those missing agents.

\subsection{Demand}

There are two periods. In period 1 investors purchase assets and in period 2 they consume. Investors can invest in three assets: two countries which pay stochastic dividends $D_{1}$ and $D_{2}$ in period 2 (and have zero residual value), and a safe asset with gross return 1. There are two investors (fund managers), $i \in\{1,2\}$. Investor $i$ 's utility is CARA with coefficient of absolute risk aversion $\gamma_{i}$. We use this assumption to allow us to derive simple closed-form solutions, although a utility function where risk aversion explicitly depended on wealth would be more desirable for our purposes.

Professional fund managers are typically judged relative to their peers. Therefore, we assume that an investor values his own period 2 wealth $W_{i}^{\prime}$ and also the difference between his wealth and that of the other investor $W_{-i}^{\prime}$.

$$
U_{i}=-e^{-\gamma_{i}\left((1-\alpha) W_{i}^{\prime}+\alpha\left(W_{i}^{\prime}-W_{-i}^{\prime}\right)\right)},
$$

where $\alpha$ measures the degree to which investors care about relative returns as opposed to absolute returns ${ }^{11}$. In period 1, investors allocate their wealth $W_{i}^{\prime}$ between each of the two countries and the safe asset.

The dividends $D_{1}$ and $D_{2}$ are stochastic. Investor 1 is relatively optimistic about country 1 and relatively pessimistic about country 2 , while investor 2 is relatively optimistic about country 2 and relatively pessimistic about country 1 . In particular,

$$
\text { investor } i \text { believes } D_{i} \sim N\left(D^{H}, \sigma^{2}\right) \text { and } D_{-i} \sim N\left(D^{L}, \sigma^{2}\right) \text {, }
$$

\footnotetext{
${ }^{10}$ The papers by Calvo and Mendoza (1999) and Schinasi and Smith (2000) take returns as exogenous, which is analogous to assuming a perfectly elastic supply of assets and exogenous prices. The papers by Kodres and Pritsker (2002), Yuan (2004), and Kyle and Xiong (2001) assume a perfectly inelastic supply of assets, so that returns and prices are endogenous but quantities are exogenous.

11 See Disyatat and Gelos (2002) for a discussion of this issue using a slightly different framework.
} 
where $D^{H}>D^{L}$. The correlation between $D_{1}$ and $D_{2}$ is $0 .{ }^{12,13}$

We now calculate the demand for the two risky assets by each investor. Let $P_{c}$ denote the price of country $c$ shares in period 1 , and $X_{i, c}$ the number of country $c$ shares held by investor $i$. Wealth levels in period 2 are thus given by

$$
W_{i}^{\prime}=W_{i}+\sum_{c=1,2} X_{i, c}\left(D_{c}-P_{c}\right)
$$

Given the properties of CARA preferences and the fact that $(1-\alpha) W_{i}^{\prime}+\alpha\left(W_{i}^{\prime}-W_{-i}^{\prime}\right)=W_{i}^{\prime}-\alpha W_{-i}^{\prime}$ is normally distributed, it is easy to show that investor $i$ maximizes

$$
\max _{X_{i, 1}, X_{i, 2}} \mathrm{E}_{i}\left[W_{i}^{\prime}-\alpha W_{-i}^{\prime}\right]-\frac{\gamma_{i}}{2} \operatorname{Var}_{i}\left[W_{i}^{\prime}-\alpha W_{-i}^{\prime}\right]
$$

where the subindices $i$ in the expectation and variance operators refer to the fact that they are calculated based on investor $i$ 's beliefs about dividends. It is easy to show that the expectation and variance terms equal

$$
\begin{gathered}
\mathrm{E}_{i}\left[W_{i}^{\prime}-\alpha W_{-i}^{\prime}\right]=W_{i}-\alpha W_{-i}+\left(X_{i, i}-\alpha X_{-i, i}\right)\left(D^{H}-P_{i}\right)+\left(X_{i,-i}-\alpha X_{-i,-i}\right)\left(D^{L}-P_{-i}\right), \\
\operatorname{Var}_{i}\left[W_{i}^{\prime}-\alpha W_{-i}^{\prime}\right]=\sigma^{2} \sum_{c=1,2}\left(X_{i, c}-\alpha X_{-i, c}\right)^{2} .
\end{gathered}
$$

There are four first order conditions, one per investor per country. They are

$$
\begin{gathered}
\frac{\partial U_{1}}{\partial X_{1,1}}=0=\left(D^{H}-P_{1}\right)-\gamma_{1} \sigma^{2}\left(X_{1,1}-\alpha X_{2,1}\right), \\
\frac{\partial U_{1}}{\partial X_{1,2}}=0=\left(D^{L}-P_{2}\right)-\gamma_{1} \sigma^{2}\left(X_{1,2}-\alpha X_{2,2}\right), \\
\frac{\partial U_{2}}{\partial X_{2,1}}=0=\left(D^{L}-P_{1}\right)-\gamma_{2} \sigma^{2}\left(X_{2,1}-\alpha X_{1,1}\right),
\end{gathered}
$$

\footnotetext{
${ }^{12}$ Since we are only concerned with the pricing and investor portfolios in period 1, the actual probability distribution of the dividends is irrelevant.

${ }^{13}$ The model can be easily extended to many investors, many countries, and non-zero correlations. However, apart from making the algebra more difficult, these extensions would not provide any additional insights.
} 


$$
\frac{\partial U_{2}}{\partial X_{2,2}}=0=\left(D^{H}-P_{2}\right)-\gamma_{2} \sigma^{2}\left(X_{2,2}-\alpha X_{1,2}\right) .
$$

The first order conditions are easy to interpret. Other things equal, an investor prefers to invest in the country about which he is relatively optimistic. However, when an investor cares about relative returns $(\alpha>0)$, he has an incentive not to choose a portfolio very different from that of the other investor. This later effect is relatively more important the more risk averse the investor is.

We now turn to the supply of assets. We consider the two polar cases of perfectly inelastic supply (fixed quantities) and perfectly elastic supply (fixed prices).

\subsection{Inelastic supply}

Let the (fixed) number of country $i$ shares be denoted by $K_{i}$. As a result, the market clearing conditions for the two assets are

$$
\begin{gathered}
K_{1}=X_{1,1}+X_{2,1}, \\
K_{2}=X_{1,2}+X_{2,2}
\end{gathered}
$$

Equations (1) through (6) form a system of 6 linear equations and 6 unknowns: $P_{1}, P_{2}, X_{1,1}, X_{1,2}$, $X_{2,1}, X_{2,2}$. After some straightforward algebra, we get

$$
\begin{aligned}
& P_{1}=\frac{D^{H}+D^{L}}{2}-\left(\frac{1}{\gamma_{1}^{-1}+\gamma_{2}^{-1}}\right) \sigma^{2}(1-\alpha) K_{1}+\left(\frac{\gamma_{2}-\gamma_{1}}{\gamma_{1}+\gamma_{2}}\right) \frac{D^{H}-D^{L}}{2}, \\
& P_{2}=\frac{D^{H}+D^{L}}{2}-\left(\frac{1}{\gamma_{1}^{-1}+\gamma_{2}^{-1}}\right) \sigma^{2}(1-\alpha) K_{2}-\left(\frac{\gamma_{2}-\gamma_{1}}{\gamma_{1}+\gamma_{2}}\right) \frac{D^{H}-D^{L}}{2}, \\
& X_{1,1}=\frac{K_{1}}{2}+\left(\frac{\gamma_{2}-\gamma_{1}}{\gamma_{1}+\gamma_{2}}\right)\left(\frac{1-\alpha}{1+\alpha}\right) \frac{K_{1}}{2}+\left(\frac{1}{\gamma_{1}+\gamma_{2}}\right)\left(\frac{1}{1+\alpha}\right) \frac{D^{H}-D^{L}}{\sigma^{2}}, \\
& X_{1,2}=\frac{K_{2}}{2}+\left(\frac{\gamma_{2}-\gamma_{1}}{\gamma_{1}+\gamma_{2}}\right)\left(\frac{1-\alpha}{1+\alpha}\right) \frac{K_{2}}{2}-\left(\frac{1}{\gamma_{1}+\gamma_{2}}\right)\left(\frac{1}{1+\alpha}\right) \frac{D^{H}-D^{L}}{\sigma^{2}} \\
& X_{2,1}=\frac{K_{1}}{2}-\left(\frac{\gamma_{2}-\gamma_{1}}{\gamma_{1}+\gamma_{2}}\right)\left(\frac{1-\alpha}{1+\alpha}\right) \frac{K_{1}}{2}-\left(\frac{1}{\gamma_{1}+\gamma_{2}}\right)\left(\frac{1}{1+\alpha}\right) \frac{D^{H}-D^{L}}{\sigma^{2}},
\end{aligned}
$$




$$
X_{2,2}=\frac{K_{2}}{2}-\left(\frac{\gamma_{2}-\gamma_{1}}{\gamma_{1}+\gamma_{2}}\right)\left(\frac{1-\alpha}{1+\alpha}\right) \frac{K_{2}}{2}+\left(\frac{1}{\gamma_{1}+\gamma_{2}}\right)\left(\frac{1}{1+\alpha}\right) \frac{D^{H}-D^{L}}{\sigma^{2}},
$$

Share prices in the two countries, $P_{1}$ and $P_{2}$, are equal to their average expected dividend, $\left(D^{H}+D^{L}\right) / 2$, plus two additional terms. The first term is due to the fact that, since the assets are risky, they need to pay a premium for investors to hold them. This effect is stronger the higher the variance of dividends $\sigma^{2}$, the higher the quantity of assets $K_{i}$, the higher the levels of risk aversion $\gamma_{i}$, and the less investors care about relative returns (low $\alpha$ ).

The second term is the most important result of the model. It shows that asset prices reflect the beliefs of the investors that are relatively less risk averse more than those of the investors that are relatively more risk averse. In other words, if investor $i$ is less risk averse than investor $-i$ the country about which investor $i$ is relatively optimistic will tend to have a higher price than the country about which investor $i$ is relatively pessimistic. The intuition is that very risk averse investors tend not to act that much on their beliefs. So the demand for the countries about which risk averse investors are optimistic is low: optimistic investors do not want to face the risk, and pessimistic investors are not interested. Since the supply is inelastic, this lower demand is reflected in lower prices. The opposite is true about countries whose optimistic investors are not very risk averse. The transmission mechanism proposed in this paper hinges on this interaction between risk aversion and beliefs.

With respect to asset allocations, each investor holds one half of each country's shares, $K_{i} / 2$, plus fractions given in two additional terms. The first term is due to the fact that the less risk averse investor will tend to hold more of each of the two assets. The second term reflects the fact that each investor will invest more in the country about which he is relatively optimistic and less in the country about which he is relatively pessimistic.

Let $b_{i, c} \equiv X_{i, c} /\left(X_{i, 1}+X_{i, 2}\right)$ be investor $i$ 's country $c$ weight, defined as the share of total investment in both countries that is invested in country $c$. The fact that an investor tends to invest more than other investors in the countries he is relatively optimistic about is reflected in the fact that $b_{1,1}>b_{2,1}$ and $b_{1,2}<b_{2,2}$ for all parameter values. ${ }^{14}$

\footnotetext{
${ }^{14}$ This can be easily shown by noting that $b_{i, i}>b_{-i, i}$ when $\alpha=1, d b_{i, i} / d \alpha<0$, and $d b_{-i, i} / d \alpha>0$. Then, it must also be true for all $\alpha \in[0,1]$. Note that we are not saying that $b_{i, i}>b_{i,-i}$.
} 
We can now describe how crises are transmitted across countries in this environment. Assume that risk aversion depends on past performance. Also assume that investors care about relative returns (positive $\alpha$ ), so that their risk aversion depends not only on past absolute returns but also on past returns in excess of those of other investors. ${ }^{15}$ Assume that there is a crisis in a third country in which investor 1 is more heavily invested because he is relatively more optimistic about that country. As a result of the crisis, investor 1 becomes more risk averse, both because he suffered absolute losses and because his losses are higher than those of investor 2. Investor 2 may or may not become more risk averse. If he cared mostly about relative returns, he would become less risk averse after suffering lower losses than investor 1 . If he cared mostly about absolute returns, he would become more risk averse, but less so than investor 1 . As a result, the crisis leads to an increase in $\gamma_{1}-\gamma_{2}$. From equations (7) and (8), we see that the price of country 1 shares would fall by a larger amount than those of country 2. Intuitively, the risk aversion of the average investor increases in country 1 more than it does in country 2 .

The model predicts that the crisis should be transmitted to a larger extent to the country that shares optimistic investors with the crisis country. Empirically, it is difficult to measure investor optimism. However, from equations (9) through (12) we see that optimism is reflected in higher country exposures. As a result, the model predicts that crises should affect to a greater extent countries that share overexposed investors with the crisis country.

When the supply of assets is perfectly inelastic, the model does not have strong predictions on portfolio adjustments in response to past investor performance. Equations (9) through (12) show that more risk averse investors invest less in both countries, but there is no interaction between differences in risk aversion and differences in optimism. The reason is that while changes in risk aversion lead to changes in asset demand, asset prices adjust so that investors end up holding the fixed quantity of assets. To study the behavior of investors' portfolios, we study next the case in which the supply of assets is perfectly elastic.

\subsection{Elastic supply}

Let the (fixed) price of country $i$ shares be denoted by $\bar{P}_{i}$. As a result, the market clearing conditions (5) and (6) are replaced by

\footnotetext{
${ }^{15}$ It would be useful to build a model in which risk aversion is endogenously determined as a function of past performance. However, building such a model is beyond the scope of this paper and is left for future work.
} 


$$
\begin{aligned}
& P_{1}=\bar{P}_{1}, \\
& P_{2}=\bar{P}_{2} .
\end{aligned}
$$

Replacing the prices in equations (1) through (4), we get a system of 4 linear equations and 4 unknowns: $X_{1,1}, X_{1,2}, X_{2,1}, X_{2,2}$. After some straightforward algebra, we get

$$
\begin{aligned}
& X_{1,1}=\frac{1}{\sigma^{2}\left(1-\alpha^{2}\right)}\left[\left(\frac{D^{H}-\bar{P}_{1}}{\gamma_{1}}\right)+\alpha\left(\frac{D^{L}-\bar{P}_{1}}{\gamma_{2}}\right)\right], \\
& X_{1,2}=\frac{1}{\sigma^{2}\left(1-\alpha^{2}\right)}\left[\left(\frac{D^{L}-\bar{P}_{2}}{\gamma_{1}}\right)+\alpha\left(\frac{D^{H}-\bar{P}_{2}}{\gamma_{2}}\right)\right], \\
& X_{2,1}=\frac{1}{\sigma^{2}\left(1-\alpha^{2}\right)}\left[\left(\frac{D^{L}-\bar{P}_{1}}{\gamma_{2}}\right)+\alpha\left(\frac{D^{H}-\bar{P}_{1}}{\gamma_{1}}\right)\right], \\
& X_{2,2}=\frac{1}{\sigma^{2}\left(1-\alpha^{2}\right)}\left[\left(\frac{D^{H}-\bar{P}_{2}}{\gamma_{2}}\right)+\alpha\left(\frac{D^{L}-\bar{P}_{2}}{\gamma_{1}}\right)\right] .
\end{aligned}
$$

An investor's portfolio decisions are driven by two effects, reflected in the two terms in the second factor. First, he wants to invest relatively more in the country he is optimistic about. This effect is stronger the larger the difference between the expected dividend (given his beliefs) and the country price, and weaker the higher his level of risk aversion. Second, he wants to invest in the country where the other investor is investing. This effect is stronger the higher the weight on relative performance $\alpha$. In addition, the first factor shows that the lower the volatility of dividends and the more investors care about relative performance, the more they invest in all countries. ${ }^{16}$

We now turn to study the properties of country weights when the supply of assets is elastic. In order for country weights to be meaningful, we need to make an additional assumption that guarantees that the total investment in the two countries, $X_{i, 1}+X_{i, 2}$, is positive for both investors. It is easy to show that $\left(\left(D^{H}+D^{L}\right) / 2-\bar{P}_{1}\right)+\left(\left(D^{H}+D^{L}\right) / 2-\bar{P}_{2}\right)>0$ is a necessary and sufficient condition for this to be the case. This condition is quite reasonable and it just states that the average country risk premium is positive. As in the case of inelastic supply of assets, the fact that an investor tends to invest

\footnotetext{
${ }^{16}$ Note that the levels of investment diverge as $\alpha \rightarrow 1$.
} 
more than other investors in the countries he is relatively optimistic about is reflected in the fact that $b_{1,1}>b_{2,1}$ and $b_{1,2}<b_{2,2}$ for all parameter values. ${ }^{17}$

How do investors' country weights respond to changes in risk aversion? In the case of a perfectly inelastic supply of assets, we showed above that changes in risk aversion do not have clear effects on portfolios, since changes in asset demand are reflected in prices but not in quantities. This is no longer the case when the quantity of assets can respond to changes in asset demand. In particular, what is the effect of an increase in the risk aversion of investor $i, \gamma_{i}$, on the portfolio of each investor? It is easy to show that

$$
\frac{d b_{i, i}}{d \gamma_{i}}<0, \frac{d b_{i,-i}}{d \gamma_{i}}>0, \frac{d b_{-i, i}}{d \gamma_{i}}<0, \frac{d b_{-i,-i}}{d \gamma_{i}}>0
$$

Namely, the investor whose risk aversion increases, decreases his weight in the country he is relatively optimistic about and increases it in the country he is relatively pessimistic about. The other investor increases his weight in the country he is optimistic about and decreases it in the country he is pessimistic about. The intuition behind these results is straightforward. The increase in risk aversion makes investor $i$ want to move his portfolio closer to that of investor $-i$. Since $b_{i, i}>b_{-i, i}$ and $b_{i,-i}<b_{-i,-i}$, this implies a shift from country $i$ to country $-i$. In turn, since investor $-i$ 's country weights also reflect an incentive not to have a portfolio very different from that of investor $i$, he responds to the shift in investor $i$ 's portfolio by shifting his own portfolio in the same direction. ${ }^{18}$

What are the predictions of the model regarding portfolio adjustments as a result of past performance? As in the case of inelastic supply, we assume that risk aversion increases when investors' past performance is weak. As a result, the model predicts that in response to past relative and absolute losses, investors should decrease (increase) their weight in countries in which their weight was higher (lower) than that of other investors. In other words, investors should move towards the average investor's portfolio by decreasing their exposure to countries in which they were overexposed and increasing their exposure to countries in which they were underexposed. In the case of relative and absolute gains, investors should move away from the average investor's portfolio by increasing their

\footnotetext{
${ }^{17}$ This can be easily shown by noting that $\lim _{\alpha \rightarrow 1} b_{i, i}=\lim _{\alpha \rightarrow 1} b_{-i, i}, d b_{i, i} / d \alpha<0$, and $d b_{-i, i} / d \alpha>0$. Then, the inequality must be true for $\alpha \in[0,1)$. Note that we are not saying that $b_{i, i}>b_{i,-i}$.

${ }^{18}$ Note that country weights are unaffected if investors do not care about relative performance $(\alpha=0)$.
} 
exposure to countries in which they were overexposed and decreasing their exposure to countries in which they were underexposed.

Note that the effect of relative performance on investors' portfolios is reinforced by a positive feedback mechanism. If investor $i$ suffers higher losses than investor $-i$, he should move towards the average portfolio. But investor $-i$ should move away from the average portfolio both because his relative performance was positive and also because the adjustment by investor $i$ shifts the average portfolio in the direction of investor $-i$ 's portfolio. This adjustment by investor $-i$ shifts the average portfolio away from investor $i$ 's, which gives investor $i$ incentives to adjust his portfolio even further from his initial portfolio. And so forth. As a result, we should expect relative performance to affect investors' portfolios more than would be suggested by the weight of relative performance in investors' utilities $\alpha$.

\subsection{Model predictions}

In sections 2.3 and 2.4, we studied separately the cases of perfectly inelastic and perfectly elastic asset supply. Under perfectly inelastic supply, we derived predictions for the transmission of crises, since in this case shifts in the demand for assets only have effects on asset prices. Under perfectly elastic supply, we derived predictions for portfolio adjustments, since in this case shifts in the demand for assets only have effects on the quantity of assets. As mentioned above, in reality the supply of assets faced by global mutual funds is likely neither perfectly elastic nor perfectly inelastic. In such an intermediate case, there would be both effects on asset prices and investors' portfolios as predicted in the cases of perfectly inelastic and perfectly elastic asset supply, respectively, although the effects would be quantitatively smaller. ${ }^{19}$

In the following sections we test the two main predictions of the model. First, we study whether poor past performance leads investors to "retrench" towards the average portfolio. We do so by regressing changes in country weights on the interaction of past performance and country overexposure. The model predicts a positive coefficient, as negative performance should lead to a decrease in the exposure to countries in which the fund is overexposed. Second, we test whether a crisis in one country is transmitted to a greater extent to countries that share overexposed investors with

\footnotetext{
${ }^{19}$ It is possible to solve analytically the same model with a supply of assets that is increasing in the price level (as long as the supply is linear in the price). However, we preferred to analyze separately the two extreme cases in which the slope is infinite or zero because they give rise to results that are much simpler and intuitive.
} 
the crisis country. We do this by constructing a matrix of financial exposure that reflects such common-investor links, and testing the power of this financial exposure matrix in predicting contagion.

\section{Data}

The mutual fund data used in this paper are from a comprehensive database purchased from eMergingPortfolio.com. The database covers, on a monthly basis, the geographic asset allocation of hundreds of equity funds with a focus on emerging markets for the period 1996:1-2000:12. The funds are domiciled in different countries around the world. At the beginning of the sample, the database contains 382 funds with assets totaling US\$117 billion. At the end of the sample, the number of funds is 639 , with US $\$ 120$ billion in assets. While the total number of funds increased over the period, some funds were dropped from the database if they discontinued providing information on their holdings.

We focus on global dedicated emerging funds, i.e. funds that invest in emerging markets worldwide. ${ }^{20}$ For stock market returns, we used monthly IFC US\$ total returns for the period 1990-2000, complementing them whenever needed with data from MSCI or national sources.

In December 2000, the subsample consisted of 117 global emerging market funds. Approximately one quarter of the funds are closed-end funds. The assets of these funds represent a modest, but not negligible fraction of the total market capitalization in the countries they invest. For example, in the case of Argentina, funds held approximately 2.7 percent of the total stock market capitalization in August of 1998, while the share was around 1.3 percent for Korea.

While precise numbers on total equity flows are hard to obtain, a substantial fraction of all equity flows to emerging markets seems to occur through the funds in our database. According to the World Bank (2003), in 1998, total portfolio equity flows to developing countries amounted to US\$7.4 billion, compared to US\$ 0.8 billion flows recorded in our sample.

The providing company aims for the widest coverage possible of emerging market funds without applying any selection criteria. According to the provider, the complete database covers roughly 80 percent of all dedicated emerging market funds, with a coverage of about 90 percent of total emerging market fund assets. We do not have data on holdings of individual stocks or on the timing of funds' purchases and sales over the month. We calculate the implied flows from the asset position data,

\footnotetext{
${ }^{20}$ For more details on the data, see Borensztein and Gelos (2003a). Kaminsky, Lyons and Schmukler (2001) also examine mutual fund behavior in emerging markets worldwide but use data at a more aggregate level.
} 
assuming that within countries, funds hold a portfolio that is well proxied by the IFC US\$ total return investable index. ${ }^{21}$ We also assume that flows occur halfway through the month.

\section{Portfolio dispersion over time}

To obtain a first impression of the data, in this section we compute the dispersion of fund portfolios over time. We measure dispersion as the root mean squared distance over country weights between each fund and the average portfolio, where the average portfolio is weighted by fund size. Figure 1 shows the median of this dispersion for the group of global funds, together with the cumulated mean fund returns (set equal to 100 at the beginning of the sample). The picture shows that fund portfolios started converging during the Asian crises, at the same time that funds started facing large portfolio losses. This suggests that during turbulent times, funds retrench towards the average. However, improvements in performance after the Russian crisis were not accompanied by an increase in fund dispersion. In the next section, we examine in detail how fund portfolio choices depend on their performance. We show that funds do retrench towards the mean during periods of low returns, but they react to returns relative to those of other funds as opposed to absolute returns. This distinction has important implications for the transmission of shocks during crises, since relative returns are very sensitive to whether funds are overexposed to crisis centers.

\footnotetext{
${ }^{21}$ This turns out to be a good approximation in emerging markets. See Borensztein and Gelos (2003a).
} 


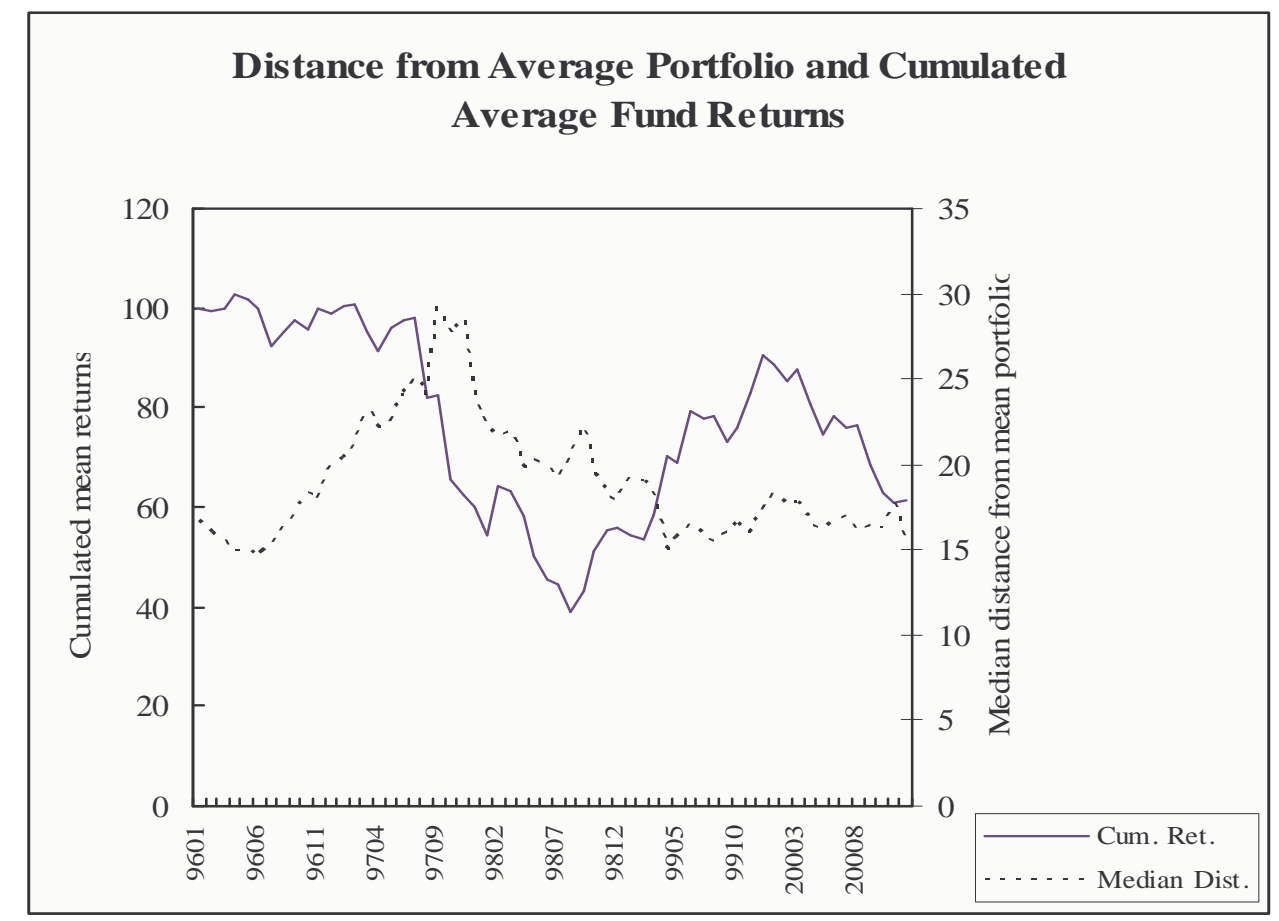

Note: Distance from average portfolio is the median portfolio distance from the mean portfolio. The mean portfolio is weighted by fund size. The distance is measured as the root mean squared difference over country weights. Based on global funds only.

\section{Fund performance and portfolio choice}

This section analyzes the trading behavior of emerging market mutual funds. We concentrate on the effect of portfolio returns - both absolute and relative to the average portfolio - on funds portfolio decisions. For this purpose, we regress changes in portfolio weights (one observation per fundcountry-date) on overexposure, excess gains (or losses), gains, and the interactions of excess gains and gains with overexposure. We find that, as predicted by the model, when fund returns are lower than that of the average portfolio, funds reduce their exposure to countries in which they were "overweight" and increase their exposure to countries in which they were "underweight

Let sub-indices $i$ denote fund, $c$ country, and $t$ time. Let $a_{i, c, t}$ denote assets and $r_{c, t}$ the stock index return. Let $s_{i, t}=\sum_{c} a_{i, c, t}$ denote the size of a mutual fund, $b_{i, c, t}=a_{i, c, t} / s_{i, t}$ its country weight, and $\bar{b}_{c, t}$ the average (weighted by fund size) country weights across funds. Let overexposure $o e_{i, c, t}$, fund gains $g_{i, t}$, and fund excess gains $\operatorname{exg}_{i, t}$ be defined as

$$
o e_{i, c, t}=b_{i, c, t}-\bar{b}_{c, t} \text {, }
$$




$$
\begin{gathered}
g_{i, t}=\sum_{c} b_{i, c, t-1} r_{c, t}, \\
\operatorname{exg}_{i, t}=g_{i, t}-\sum_{c} \bar{b}_{c, t-1} r_{c, t} .
\end{gathered}
$$

The change in country weight, $d b_{i, c, t}$, is given by

$$
d b_{i, c, t}=b_{i, c, t}-b_{i, c, t-1} .
$$

It is not clear that we should focus on $d b_{i, c, t}$ as a measure of portfolio adjustment by funds. For example, if the market capitalization of a country as a fraction of total world market capitalization changed, one would expect that, on average, mutual funds' country weights would adjust as well. In particular, it is obvious that it would not be possible for all investors (mutual funds and others) to keep a constant country weight.

At one extreme, if the supply of assets were totally inelastic market capitalization would change proportionately to country returns $r_{c, t} \cdot{ }^{22}$ As a result, even if funds acted passively without buying or selling shares, the country weight would change by an amount ${ }^{23}$

$$
\operatorname{adj}_{i, c, t}=\left(\frac{b_{i, c, t-1}}{1+g_{i, t}}\right)\left(r_{c, t}-g_{i, t}\right) .
$$

In this case, one would want to use an "adjusted" change in weights, $d b_{i, c, t}^{\prime}$, that solely captured the change in weights that arose from funds actively buying and selling assets,

$$
d b_{i, c, t}^{\prime}=d b_{i, c, t}-a d j_{i, c, t} .
$$

From the discussion in section 2.2, we see that share prices and expected returns would adjust in order to keep investors content holding the resulting portfolio. For example, if in one country returns are lower than average, we would expect share prices not to fall proportionately as much as expected

\footnotetext{
${ }^{22}$ This would not be exactly true if firms paid dividends. However, at monthly frequencies dividends are not an important fraction of returns, especially for emerging markets.

${ }^{23}$ This follows from the fact that if the fund did not buy or sell any assets, its weight in country $c$ at time $t$ would equal $b_{i, c, t}=\left(\frac{1+r_{c, t}}{1+g_{i, t}}\right) b_{i, c, t-1}$.
} 
dividends, since the expected returns need to fall to keep investors from wanting to reestablish their prior country weights.

At the other extreme, if the supply of assets were totally elastic expected returns would remain constant and, thus, we would expect funds to keep constant country weights. In this case, one would want to use the unadjusted change in weights, $d b_{i, c, t}$, in the regressions. Finally, for intermediate cases one would want to adjust $d b_{i, c, t}$, but by less than in equation (20).

We run the following regression

$$
d b_{i, c, t}=\alpha \cdot o e_{i, c, t-1}+\beta \cdot a d j_{i, c, t}+\gamma \cdot \operatorname{exg}_{i, t}+\delta \cdot o e_{i, c, t-1} \cdot \operatorname{exg}_{i, t}+\varepsilon_{i, c, t} .
$$

The first term captures possible mean reversion in portfolios. The role of the second term should be clear from the discussion above. We run three types of regressions: one constraining $\beta$ to be 1 which corresponds to the case of perfectly inelastic supply, one constraining $\beta$ to be 0 which corresponds to the case of perfectly elastic supply, and one in which $\beta$ is unconstrained, letting the regression tell us what the appropriate adjustment term is.

If our hypothesis were true, fund $i$ should increase its weight on country $c\left(d b_{i, c, t}\right.$ positive) if the fund was overexposed to country $c$ ( $o e_{i, c, t-1}$ positive) when the fund is doing relatively well $\left(\operatorname{exg}_{i, t}\right.$ positive). Likewise, the fund should increase its weight on country $c$ ( $d b_{i, c, t}$ positive) if the fund was underexposed to country $c$ ( $o e_{i, c, t-1}$ negative) when the fund is doing relatively badly ( $\operatorname{exg}_{i, t}$ negative). As a result, we focus on the coefficient $\delta$, which should be positive according to our hypothesis.

Funds indeed tend to buy into countries in which they are overexposed (underexposed) when their gains are higher (lower) than that of other funds. Tables 1.a and 1.b summarize our results for the three cases in which $\beta \equiv 1, \beta \equiv 0$, and $\beta$ is unconstrained. ${ }^{24}$ We report results including excess gains as well as gains to determine whether funds care more about relative or absolute performance. In all cases, the coefficient $\delta$ is positive and statistically significant at the $1 \%$ level. There is also a significant reversion to the mean in the sense that on average funds buy into countries were they are

\footnotetext{
${ }^{24}$ We restricted the sample to countries that represent at least $1 \%$ of average fund portfolio. We observed that we could explain portfolio adjustments for large countries better than for small countries. One possible explanation is that the index is mismeasured for small countries due to rounding off in portfolio reporting by funds. The raw data indeed seems to be rounded.
} 
underexposed. ${ }^{25}$ It is interesting to note that excess gains seem to be more important than absolute gains, both in levels and when interacted with overexposure. When including absolute gains, the interaction term of lagged overexposure and absolute gains is small and not always significant. Finally, when unconstrained, the coefficient on the adjustment term is always significantly greater than 0 and significantly lower than 1 , suggesting that indeed mutual funds face neither a perfectly elastic nor a perfectly inelastic supply of assets.

The economic significance of the effect of funds' relative performance on whether or not they retrench to the benchmark is moderate, but by no means negligible. For example, consider a country in which half the funds (weighted by fund size) invest $15 \%$ of their assets and half the funds invest $5 \%$ of their assets, so that the former have overexposure of $+5 \%$ and the latter of $-5 \%$. Assume that the first group of funds has losses of $10 \%$ while the second group has gains of 10. According to the results in Table 1.a (unconstrained $\beta$ ), both groups of funds would reduce their weight in the country by $0.44 \%$. In addition, the first group of funds will now manage $0.5 * 90 \%$ of total fund assets while the second group of funds will correspond to $0.5 * 110 \%$ of total fund assets. As a result, the average weight of the country in total fund assets would drop from $10 \%$ to $9.07 \%$, which implies that total funds' investment in the country would drop by almost $10 \%$. In addition, the $10 \%$ drop in funds' investment in the country would take place despite the fact that the expected returns in the country would have increased, since the supply of assets is not perfectly elastic.

We have also run regressions including control variables. There, we added variables such as changes in risk as reported by the International Country Risk Guide; we included such control variables independently and as interactions with lagged excess gains. While many of these variables helped to improve the fit of our regressions, none significantly reduced the importance of the channel stressed here. The results are reported in Appendix II. ${ }^{26}$

\footnotetext{
${ }^{25}$ Of course, this does not mean that there is a trend and that over time funds are getting closer to the mean.

${ }^{26}$ In an earlier version, we also looked at the differences between open-end and closed-end funds. We found that the two types of funds behave similarly. The coefficient $\delta$ was always positive and significant at the $1 \%$ level, and its magnitude was slightly higher for closed-end funds.
} 
Table 1.a: Portfolio adjustment

\begin{tabular}{l|ccc}
\hline \hline & $\begin{array}{c}\text { Assuming inelastic } \\
\text { supply } \\
(\beta \equiv 1)\end{array}$ & $\begin{array}{c}\text { Assuming perfectly } \\
\text { elastic supply } \\
(\beta \equiv 0)\end{array}$ & $\begin{array}{c}\text { No assumption on } \\
\text { supply elasticity } \\
(\beta \text { unconstrained })\end{array}$ \\
\hline \hline adjustment term & 1 & 0 & $\begin{array}{c}0.436^{* * * * *} \\
(0.007)\end{array}$ \\
\hline overexposure (t-1) & $-0.044^{* * * *}$ & $-0.069^{* * * *}$ & $-0.061^{* * * *}$ \\
excess gains & $(0.002)$ & $(0.002)$ & $(0.002)$ \\
overexposure $(\mathrm{t}-1)$ & $3.360^{* * *}$ & $-0.831^{* * *}$ & $\left(045^{* * * *}\right.$ \\
$\times$ excess gains & $(0.23)$ & $(0.244)$ & $0.233)$ \\
\hline Observations & $0.647^{* * *}$ & $1.035^{* * * *}$ & $(0.090)$ \\
$R^{2}$ & $(0.092)$ & $(0.094)$ & 38,353 \\
\hline \hline
\end{tabular}

Notes: Dependent variable: change in country weight, as defined in equation (20).

One observation per fund-time-country. All variables normalized by beginning of period fund size. ${ }^{* * * * * *}$, and ${ }^{*}$ means statistical significance at the $1 \%, 5 \%$, and $10 \%$ level respectively.

Table 1.b: Portfolio adjustment

\begin{tabular}{|c|c|c|c|c|c|c|}
\hline & $\begin{array}{l}\text { Assuming } \\
\text { inelastic } \\
\text { supply }\end{array}$ & $\begin{array}{l}\text { Assuming } \\
\text { inelastic } \\
\text { supply }\end{array}$ & $\begin{array}{c}\text { Assuming } \\
\text { perfectly elastic } \\
\text { supply }\end{array}$ & $\begin{array}{l}\text { Assuming } \\
\text { perfectly } \\
\text { elastic } \\
\text { supply }\end{array}$ & $\begin{array}{c}\text { No assumption } \\
\text { on supply } \\
\text { elasticity }\end{array}$ & $\begin{array}{c}\text { No } \\
\text { assumption } \\
\text { on supply } \\
\text { elasticity }\end{array}$ \\
\hline Adjustment term & 1 & 1 & 0 & 0 & $\begin{array}{l}0.435^{* * * *} \\
(0.007)\end{array}$ & $\begin{array}{l}0.433^{* * * *} \\
(0.007)\end{array}$ \\
\hline overexposure (t-1) & $\begin{array}{l}-0.044^{\text {***** }} \\
(0.002)\end{array}$ & $\begin{array}{l}-0.045^{\text {**** }} \\
(0.002)\end{array}$ & $\begin{array}{l}-0.069^{\text {**** }} \\
(0.002)\end{array}$ & $\begin{array}{c}-0.070^{* * * *} \\
(0.002)\end{array}$ & $\begin{array}{c}-0.061^{\text {*3*** }} \\
(0.002)\end{array}$ & $\begin{array}{c}-0.061^{* * * *} \\
(0.002)\end{array}$ \\
\hline excess gains & $\begin{array}{l}3.289^{* * * *} \\
(0.253)\end{array}$ & - & $\begin{array}{c}-1.568^{* * * *} \\
(0.262)\end{array}$ & - & $\begin{array}{l}0.588^{* * *} \\
(0.251)\end{array}$ & - \\
\hline $\begin{array}{l}\text { overexposure }(\mathrm{t}-1) \\
\times \text { excess gains }\end{array}$ & $\begin{array}{l}0.843^{* * * *} \\
(0.100)\end{array}$ & - & $\begin{array}{l}1.211^{* * * *} \\
(0.102)\end{array}$ & 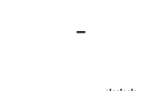 & $\begin{array}{l}1.062^{* * * *} \\
(0.097)\end{array}$ & - \\
\hline Gains & $\begin{array}{l}0.106^{*} \\
(0.078)\end{array}$ & $\begin{array}{l}0.487^{* * * *} \\
(0.072)\end{array}$ & $\begin{array}{l}0.651^{* * *} \\
(0.080)\end{array}$ & $\begin{array}{l}0.488^{* * *} \\
(0.074)\end{array}$ & $\begin{array}{l}0.420^{* * * *} \\
(0.076)\end{array}$ & $\begin{array}{l}0.500^{* * *} \\
(0.071)\end{array}$ \\
\hline $\begin{array}{l}\text { overexposure }(\mathrm{t}-1) \\
\times \text { gains } \\
\end{array}$ & $\begin{array}{c}-0.173 * * * \\
(0.034)\end{array}$ & $\begin{array}{c}-0.053^{\text {**** }} \\
(0.031)\end{array}$ & $\begin{array}{c}-0.179^{\text {***** }} \\
(0.034)\end{array}$ & $\begin{array}{l}-0.028 \\
(0.032)\end{array}$ & $\begin{array}{c}-0.182^{* * * *} \\
(0.032)\end{array}$ & $\begin{array}{l}-0.043 \\
(0.030)\end{array}$ \\
\hline Observations & 40,946 & 40,946 & 38,353 & 38,353 & 38,353 & 38,353 \\
\hline$R^{2}$ & 0.02 & 0.01 & 0.03 & 0.02 & 0.12 & 0.12 \\
\hline
\end{tabular}

Notes: Dependent variable: change in country weight, as defined in equation (20). One observation per fund-time-country. All variables normalized by beginning of period fund size. $^{* * * *},{ }^{* *}$, and ${ }^{*}$ means statistical significance at the $1 \%, 5 \%$, and $10 \%$ level respectively. 


\section{A measure of financial interdependence}

The results in the previous section suggest that the effect of crises on fund flows depends on funds' degree of overexposure to the crisis country. In particular, since the funds that were overexposed to the crisis country are likely to have larger losses than those that were underexposed, we should expect those funds to take capital out of the countries in which they were overexposed and into the countries in which they were underexposed.

In this section we construct a matrix of financial interdependence between countries based on whether countries share overexposed investors. We define country $c_{l}$ 's reliance on fund $i, r e_{c_{1}, i, t}$, as the contribution of fund $i$ to total investment in the country by all funds,

$$
r e_{c_{1}, i, t}=\frac{a_{i, c_{1}, t}}{\sum_{i^{\prime}} a_{i^{\prime}, c_{1}, t}} .
$$

We define country $c_{1}$ 's reliance on investors overexposed to country $c_{2}, d_{c_{1}, c_{2}, t}$, as

$$
d_{c_{1}, c_{2}, t}=\sum_{i} r e_{c_{1}, i, t} \times o e_{i, c_{2}, t},
$$

namely, the sum of every fund's overexposure to country $c_{2}$, weighted by $c_{1}$ 's reliance on each fund. For short, we also refer to $d_{c_{1}, c_{2}, t}$ as country $c_{1}$ 's exposure to country $c_{2}$. The relationship between this definition of exposure and the results in section 5 can be illustrated by noting that $d_{c_{1}, c_{2}, t}$ can be rewritten as

$$
d_{c_{1}, c_{2}, t}=\sum_{i} \frac{s_{i}}{S} \frac{o e_{i, c_{1}, t}}{\bar{b}_{c_{1}, t}} \times o e_{i, c_{2}, t},
$$

where $S=\sum_{i} s_{i}$, the sum of the assets of all funds (see Appendix III for details). As shown in section 5 , a fund should reduce its investments in country $c_{1}$ in response to low excess gains if that fund is overexposed to country $c_{l}$. This explains why the exposure measure is related to the correlation between funds overexposure to the crisis country and to $c_{l}$. The reason why $o e_{i, c_{1}, t}$ is divided by $\bar{b}_{c_{1}, t}$ is 
that the effect of a given reduction in funds investments in country $c_{1}$ will depend on the size of that reduction relative to total investments in the country. That is why the exposure measure is not symmetric, $d_{c_{1}, c_{2}, t} \neq d_{c_{2}, c_{1}, t}$. Note that this does not mean that small countries are, in general, more exposed to crises, since funds overexposure to small countries tends to be small. On the other hand, it is true that countries, in general, have low exposures to small countries. ${ }^{27}$

\section{Financial interdependence and contagion}

We have shown that, on average, funds take their capital out of countries that rely heavily on funds overexposed to crisis countries. Does this mean that the matrix of financial exposure can predict which countries are likely to be affected by contagion? In particular, in this section we study whether the degree of financial exposures to crisis countries can help explain the cross-section of stock returns during crises. Given that we are examining only a subset of international investors, a positive finding could be interpreted as an indication that mutual funds are representative of international investors in general.

We find that our index of financial exposure helps explain the pattern of cross-country stock market movements during the Thai, Russian and Brazilian crises (Table 2a). ${ }^{28}$ For the three crises, we run three separate regressions of stock market returns on exposure restricting the sample to countries that represent at least $1 \%, 2 \%$, and $3 \%$ of average fund portfolio respectively. ${ }^{29}$ For all crises, the coefficient on the financial exposure variable is negative and statistically significant. For the Thai crisis, the financial exposure variable is significant at the $1 \%$ level. Furthermore, the exposure variable explains between $28 \%$ and $52 \%$ of the cross-sectional variation in country returns. For the Russian crisis, the financial exposure variable is significant at the $5 \%$ level and explains $15 \%$ of the cross-

\footnotetext{
${ }^{27}$ This index only takes into account "direct" links. Higher order links can be calculated estimating first the effect of the direct link, adding higher order terms discounted using this estimated effect, and iterating.

${ }^{28}$ The crisis dates were chosen as follows: In Thailand, difficulties were apparent since the beginning of 1997, the currency was devalued in June, and the biggest drop in the stock market took place in August. As a result, for the Thai crisis we study accumulated stock market returns during the period April 1997 - August 1997. In Russia, interest rates on T-bills increased substantially in July 1998, the default took place in August, and the large drops in the stock market took place in August and September. As a result, for the Russian crisis we study accumulated stock market returns during the period July 1998 - September 1998. In Brazil, it is difficult to pinpoint to a start of the crisis, as pressure started mounting beginning with the Russian default. As a result, for the Brazilian crisis we study the returns during January 1999, the month when both the devaluation and the largest stock market drop took place.

${ }^{29} \mathrm{We}$ observed that the index of financial interdependence explains returns in large countries better than in small countries. This parallels our finding that portfolio adjustments could also be explained for large countries better than for small countries.
} 
sectional variation in country returns. However, it loses significance when restricting the regression to countries with weights higher than $3 \%$, although this regression only has 9 observations. For the Brazilian crisis, the financial exposure variable is significant at the $10 \%$ level for countries with weights greater than $1 \%$. In addition, both significance and explanatory power increase, as the sample is restricted to larger countries. For countries with weights greater than $3 \%$, the exposure variable explains $45 \%$ of the cross-sectional variation in stock returns.

Table 2a. Stock market returns during crises

\begin{tabular}{|l|ccc|cccc|ccc|}
\hline \hline & \multicolumn{3}{|c|}{ Thailand } & \multicolumn{3}{c|}{ Russia } & \multicolumn{3}{c|}{ Brazil } \\
\cline { 2 - 11 } & weight $>1$ & weight>2 & weight $>3$ & weight $>1$ & Weight $>2$ & weight $>3$ & weight $>1$ & weight $>2$ & weight $>3$ \\
\hline Financial & $-0.368^{* * *}$ & $-0.504^{* * *}$ & $-0.520^{* * *}$ & $-0.081^{* *}$ & $-0.057^{*}$ & -0.050 & $-0.021^{*}$ & $-0.039^{*}$ & $-0.096^{* *}$ \\
Exposure & $(0.124)$ & $(0.093)$ & $(0.104)$ & $(0.033)$ & $(0.031)$ & $(0.066)$ & $(0.012)$ & $(0.020)$ & $(0.043)$ \\
\hline$R^{2}$ & 0.28 & 0.52 & 0.52 & 0.15 & 0.09 & 0.06 & 0.08 & 0.20 & 0.45 \\
\hline No. of obs. & 19 & 14 & 12 & 19 & 15 & 9 & 21 & 14 & 10 \\
\hline \hline
\end{tabular}

Notes: Stock market returns as a function of a country's exposure to crisis countries. The Thai crisis regression corresponds to cumulative returns during April 1997-August 1997, the Russian crisis regression to July 1998-September 1998, and the Brazilian crisis regression to January 1999. Weight refers to the minimum weight of a country in the average portfolio to be included in regressions. Exposure variable lagged one from beginning of crisis. Crisis countries excluded from regressions. ${ }^{* * * * *}$, and ${ }^{*}$ means statistical significance at the $1 \%, 5 \%$, and $10 \%$ level respectively. Robust standard errors are shown in parentheses.

Figure 2 illustrates the effect of exposure on returns, restricting the sample to countries with weights greater than $1 \%$. First, it seems clear that the results are not due to outliers. Second, it shows that focusing on financial exposure, we can explain why some countries with no other obvious links to the crisis country suffered contagion, while others that ex-ante might have seemed connected did not. During the Thai crisis, among the Asian countries Taiwan was relatively unaffected, perhaps due to the fact that it did not share overexposed investors with Thailand. Malaysia, on the other hand, was the country most affected and also the country most exposed. During the Brazilian crisis, Argentina was the country most exposed and also one of the 3 with lowest returns and the lowest among LatinAmerican countries. In addition, both among European countries and among Asian countries, those with high exposure had lower returns than those with low exposure (China being the exception). 
Figure 2. Exposure to Crisis Country and Stock Market Returns

Thai crisis

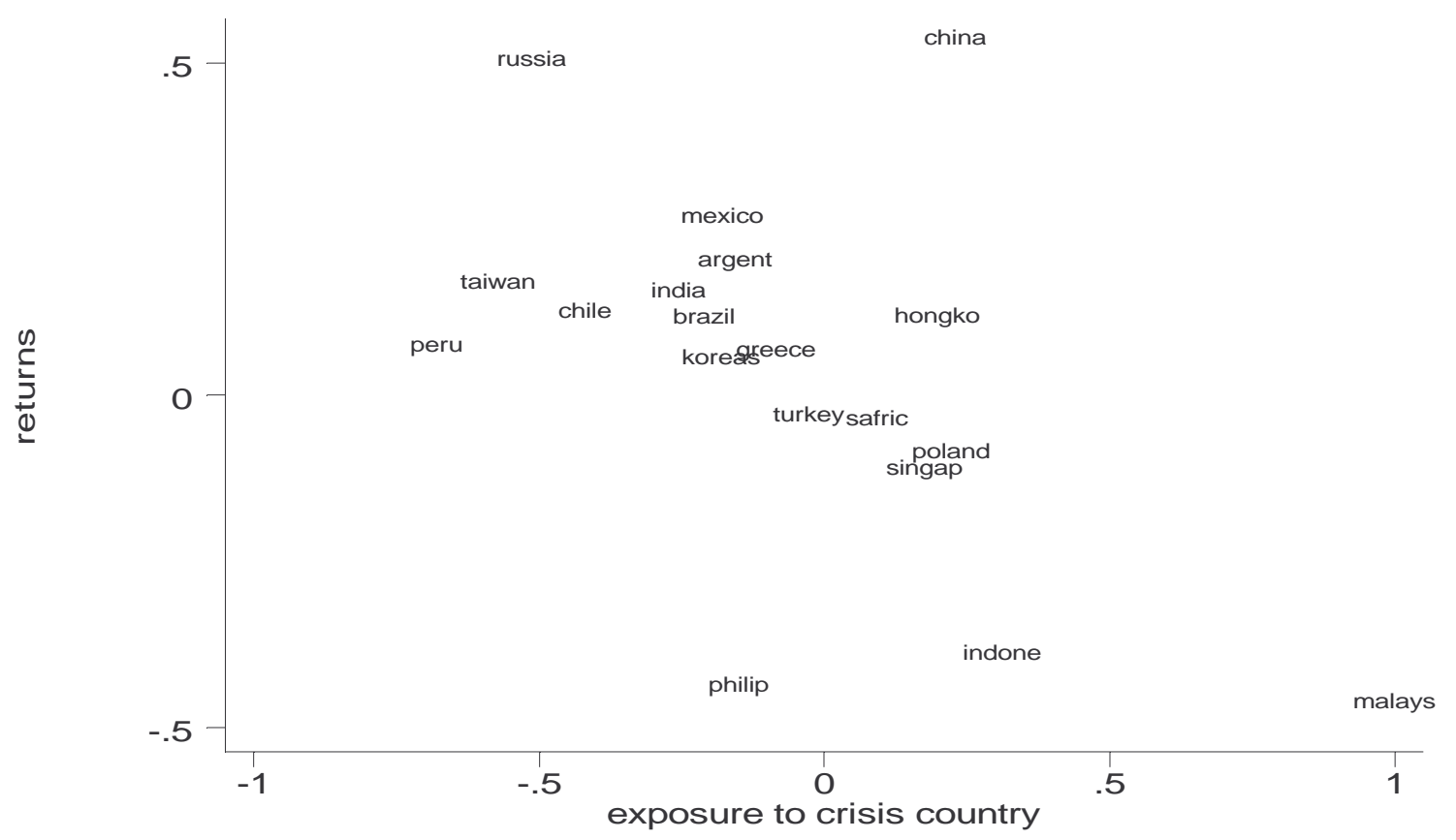

Russian crisis

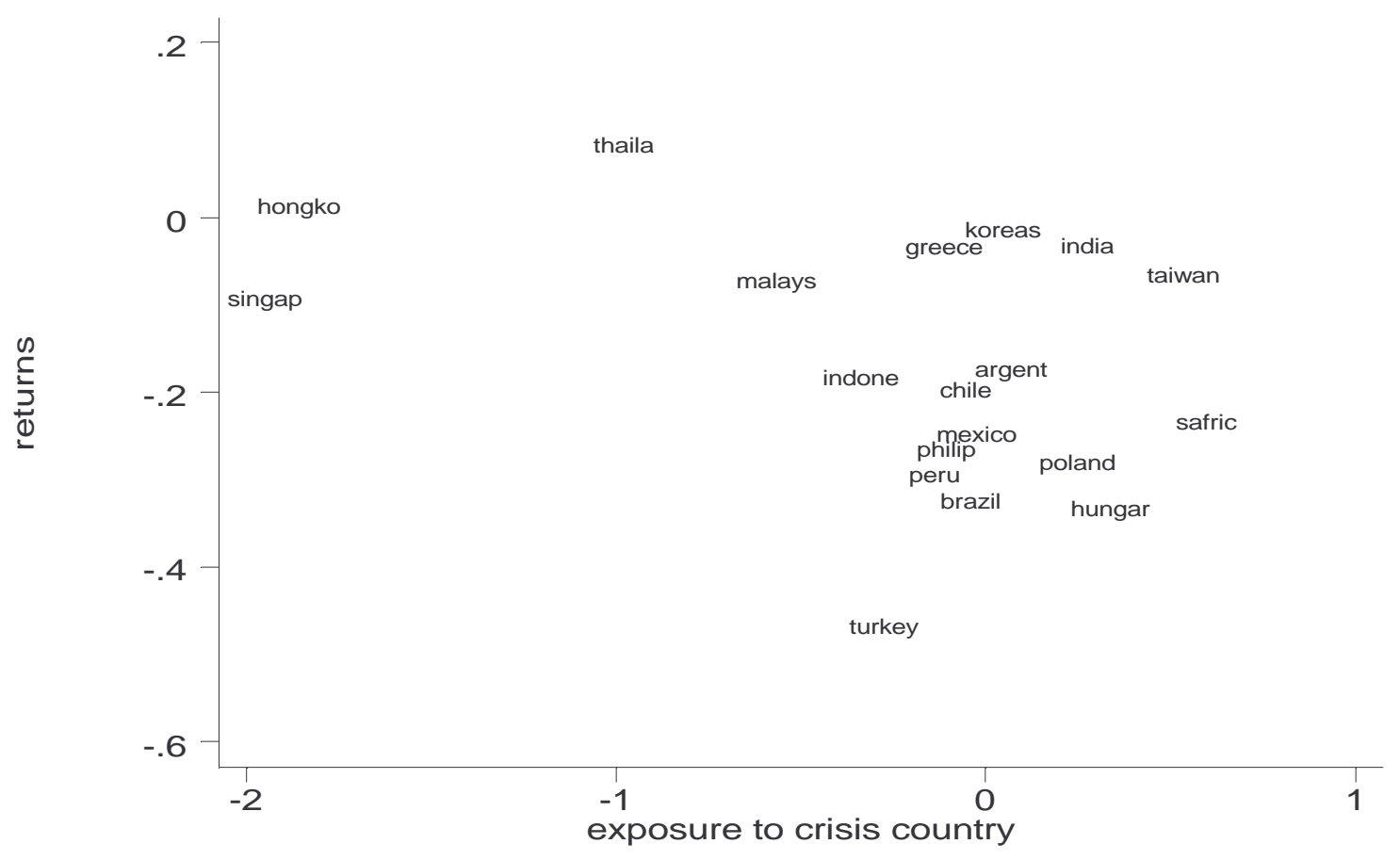




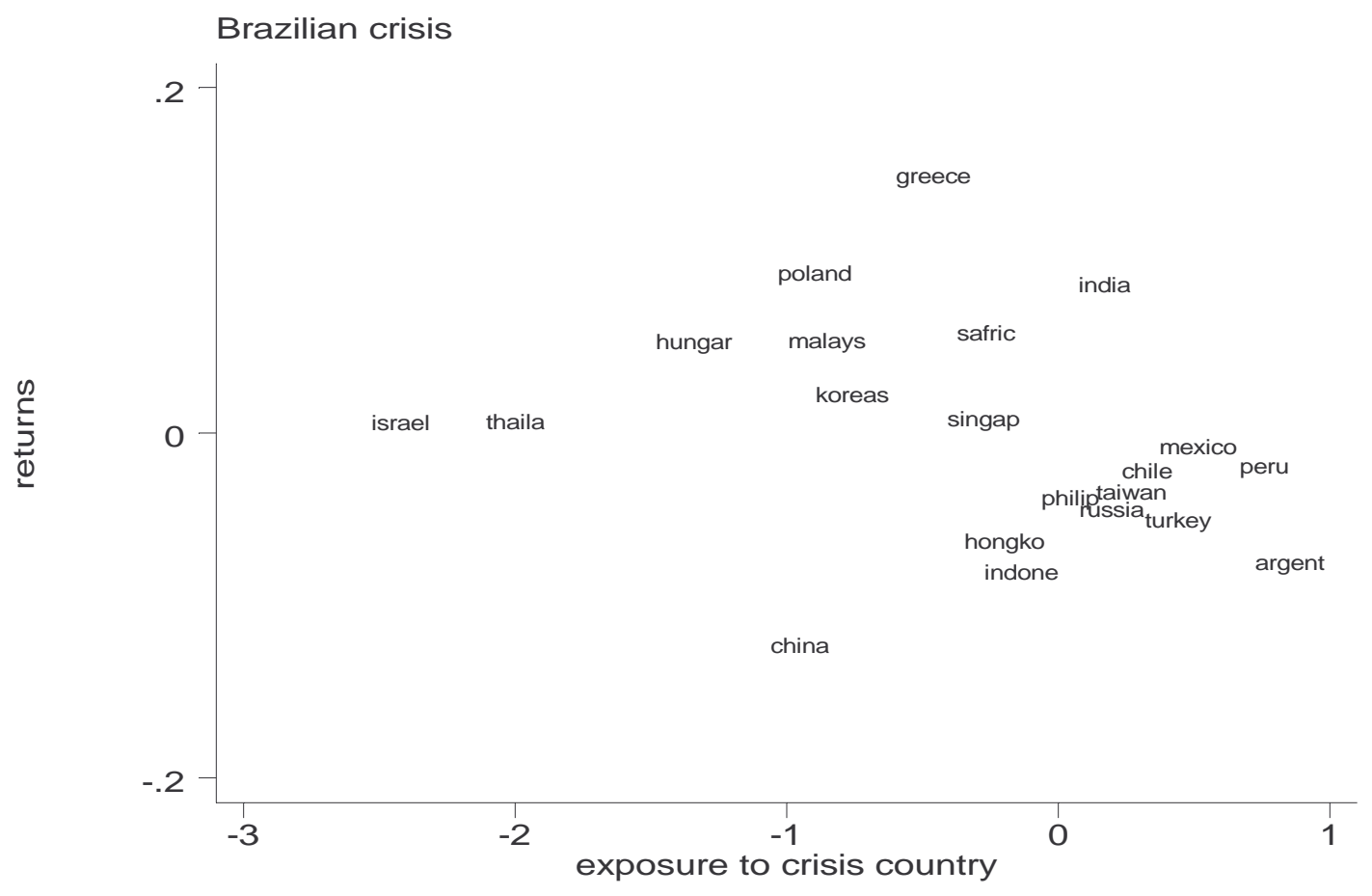

Next, we examine the importance of two important control variables, adding them one at a time to each regression (Table $2 \mathrm{~b}$ ). First, the presence of trade linkages is an important candidate for explaining the pattern of financial shock comovements across countries. Therefore, we include an index of the degree of direct trade competition as used in Van Rijckeghem and Weder (2001). Second, we use two variables measuring the degree to which country $i$ competes for funding from the same bank lenders as the crisis country, as proposed by Van Rijckeghem and Weder (2001). ${ }^{30}$ The first of these indices is based on the absolute value of credits obtained from the common lender, and the second is based on the share of borrowing from the common lender. Due to the limited number of observations, we cannot include lists of potentially relevant macroeconomic fundamentals. ${ }^{31}$

\footnotetext{
${ }^{30}$ See "funds competition" in Table 1, p. 300 in Van Rijckeghem and Weder (2001). We are grateful to the authors for sharing their data with us. (The Brazil crisis was not covered in their study and we constructed the data for this case.) ${ }^{31}$ We experimented with probabilities of currency crises as predicted by the early warning system used at the IMF and described in Berg and Pattillo (1999). This variable summarizes the information contained in a variety of macroeconomic variables. However, it is only available for a subset of countries in our sample, reducing our sample size further. When included, the variable was never significant at the five percent confidence level.
} 
Table 2 b. Stock market returns during crises, including control variables

\begin{tabular}{|c|c|c|c|c|c|c|c|}
\hline & Thailand & Thailand & Thailand & Thailand & Thailand & Thailand & Thailand \\
\hline $\begin{array}{l}\text { Financial Exposure } \\
\text { (lagged) }\end{array}$ & $\begin{array}{l}-0.368 * * * \\
(0.124)\end{array}$ & - & - & - & $\begin{array}{l}-0.324 * * * \\
(0.106)\end{array}$ & $\begin{array}{c}-0.378 * * * \\
(0.088)\end{array}$ & $\begin{array}{l}-0.406^{* * * *} \\
(0.115)\end{array}$ \\
\hline Trade Competition & - & $\begin{array}{l}-0.551 \\
(0.387)\end{array}$ & - & - & $\begin{array}{l}-0.366 \\
(0.275)\end{array}$ & - & - \\
\hline $\begin{array}{l}\text { Competition for bank funds } \\
\text { (share) }\end{array}$ & - & - & $\begin{array}{l}-0.608 \\
(0.503)\end{array}$ & - & - & $\begin{array}{r}0.039 \\
(0.458)\end{array}$ & - \\
\hline $\begin{array}{l}\text { Competition for bank funds } \\
\text { (absol.ute) }\end{array}$ & - & - & - & $\begin{array}{c}0.319 \\
(0.334)\end{array}$ & - & - & $\begin{array}{c}0.472 \\
(0.328)\end{array}$ \\
\hline$R^{2}$ & 0.28 & 0.13 & 0.11 & 0.04 & 0.33 & 0.28 & 0.37 \\
\hline $\begin{array}{l}\text { No. of } \\
\text { obs. }\end{array}$ & 19 & 19 & 19 & 19 & 19 & 19 & 19 \\
\hline
\end{tabular}

\begin{tabular}{|c|c|c|c|c|c|c|c|}
\hline & Russia & Russia & Russia & Russia & Russia & Russia & Russia \\
\hline $\begin{array}{l}\text { Financial Exposure } \\
\text { (lagged) }\end{array}$ & $\begin{array}{c}-0.081 * * \\
(0.033) \\
\end{array}$ & - & - & - & $\begin{array}{l}-0.039 \\
(0.043) \\
\end{array}$ & $\begin{array}{l}-0.023 \\
(0.039) \\
\end{array}$ & $\begin{array}{c}-0.084 * * \\
(0.033) \\
\end{array}$ \\
\hline Trade Competition & - & $\begin{array}{c}-3.996 * * \\
(1.682)\end{array}$ & - & - & $\begin{array}{l}-3.537^{*} \\
(1.923)\end{array}$ & - & - \\
\hline $\begin{array}{l}\text { Competition for bank funds } \\
\text { (share) }\end{array}$ & - & - & $\begin{array}{c}-0.827 * * * \\
(0.255) \\
\end{array}$ & - & - & $\begin{array}{l}-0.732 * \\
(0.362) \\
\end{array}$ & - \\
\hline $\begin{array}{l}\text { Competition for bank funds } \\
\text { (absol.ute) }\end{array}$ & - & - & - & $\begin{array}{l}-0.096 \\
(0.254) \\
\end{array}$ & - & - & $\begin{array}{l}-0.150 \\
(0.239) \\
\end{array}$ \\
\hline$R^{2}$ & 0.15 & 0.18 & 0.30 & 0.01 & 0.20 & 0.32 & 0.17 \\
\hline $\begin{array}{l}\text { No. of } \\
\text { obs. }\end{array}$ & 19 & 18 & 19 & 19 & 18 & 19 & 19 \\
\hline
\end{tabular}

\begin{tabular}{|l||ccccccc||}
\hline & Brazil & Brazil & Brazil & Brazil & Brazil & Brazil & Brazil \\
\hline \hline $\begin{array}{l}\text { Financial Exposure } \\
\text { (lagged) }\end{array}$ & $\begin{array}{c}-0.021^{*} \\
(0.021)\end{array}$ & - & - & - & $\begin{array}{c}-0.016 \\
(0.012)\end{array}$ & $\begin{array}{c}-0.028^{*} \\
(0.015)\end{array}$ & $\begin{array}{c}-0.025 \\
(0.019)\end{array}$ \\
\hline \hline Trade Competition & - & $\begin{array}{c}-0.713^{* * *} \\
(0.200)\end{array}$ & - & - & $\begin{array}{c}-0.581^{* *} \\
(0.250)\end{array}$ & - & - \\
\hline $\begin{array}{l}\text { Competition for bank } \\
\text { Funds (share) }\end{array}$ & - & - & $\begin{array}{c}0.001 \\
(0.137)\end{array}$ & - & - & $\begin{array}{c}0.013 \\
(0.138)\end{array}$ & - \\
\hline \hline $\begin{array}{l}\text { Competition for bank funds } \\
\text { (absol.ute) }\end{array}$ & - & & & $\begin{array}{c}-0.095 \\
(0.209)\end{array}$ & - & - & $\begin{array}{c}0.078 \\
(0.284)\end{array}$ \\
\hline \hline R2 & 0.08 & 0.10 & 0.00 & 0.01 & 0.14 & 0.10 & 0.08 \\
\hline \hline $\begin{array}{l}\text { No. of } \\
\text { obs. }\end{array}$ & 21 & 21 & 21 & 21 & 21 & 21 & 21 \\
\hline \hline
\end{tabular}

Notes: Stock market returns as a function of a country's exposure to crisis countries. The Thai crisis regression corresponds to cumulative returns during April 1997-August 1997, the Russian crisis regression to July 1998 - September 1998, and the Brazilian crisis regression to January 1999. Includes only countries with an average weight in fund portfolios of at leas one percent. Exposure variable lagged one from beginning of crisis. Crisis countries excluded from regressions. ${ }^{* * * *},{ }^{* *}$, and ${ }^{*}$ means statistical significance at the $1 \%, 5 \%$, and $10 \%$ level respectively. Robust standard errors are shown in parentheses. For the variables "trade competition" and "competition for bank funds" see Van Rijckeghem and Weder (2001). "Absolute" competition for bank funds is based on the value of credits obtained from the common lender, "share" is based on the share of borrowing from the common lender. 
The small number of observations limits inference but some patterns are observable. For the Thai crisis, none of the control variables are significant in explaining the pattern of the stock market reaction across countries, and the coefficient on our financial exposure variable remains broadly unchanged and statistically significant when including either control variable at a time. For the Russian crisis, the trade variable is significant and alone explains a similar share of the total variance in stock returns. The "absolute" bank competition variable used by Van Rijckeghem and Weder (2001) for the Russian crisis does not enter significantly. However, the "share"-based bank competition variable is significant, and explains 30 percent of stock returns variation. When including both the financial exposure index and one of the two control variables at a time, the financial exposure index becomes insignificant when including the trade competition variable or the "share"-based bank competition index. The financial exposure variable, does however, survive the inclusion of the "absolute" bank competition index. For the Brazil crisis, the pattern is similar: trade linkages matter, and the financial interdependence variable remains statistically significant when controlling for bank linkages (which do not seem to matter) but becomes insignificant when adding trade competition. ${ }^{32}$

\section{Conclusions}

We have shown that the portfolio choices of international funds depend on their past relative performance. In particular, they respond to relative losses (gains) by moving closer (further away) to (from) the average portfolio. These results are consistent with the hypothesis that fund managers' effective risk aversion depends on their fund's relative performance.

This behavior by international funds can help explain why some countries are affected by financial market spillovers even if they do not seem to share fundamental weaknesses with crisis countries. We constructed an index of financial interdependence reflecting the extent to which countries share "overexposed" funds. We found that this index contributes to explain the pattern of stock returns during three crises. In the case of the Thai crisis, it outperforms trade and bank linkages as explanatory variable, while for the Russian and Brazilian crises, trade linkages seem to be at least as important in explaining the extent to which other countries were affected. These results suggest that our index of

\footnotetext{
32 Johnson et al (2000) have argued that corporate governance indices can help explain the pattern of stock market declines during the Asian crisis. In a related vein, Gelos and Wei (2002), show that funds tend to avoid intransparent countries during crises. We did not investigate this issue here but plan to address it in future research.
} 
financial interdependence could be helpful in predicting which countries are likely to be affected by a crisis in a particular country.

The tendency of mutual funds to reduce their overexposures in response to low relative performance may exacerbate the effect of crises, by creating both contagion between countries and momentum trading at the country level. This prompts the question of whether countries should limit participation of international funds in their stock markets to index funds (i.e., funds that passively follow the index). However, we believe that such a measure would likely be counterproductive. Information gathering by investors such as emerging market funds plays a useful role, and if all investors blindly followed indices, the indices themselves might become arbitrary, yielding herding in an extreme form. ${ }^{33}$

Lastly, the predictive power of our index of financial exposure based on international mutual funds likely reflects the fact that these funds are representative of other kinds of investors, such as commercial and investment banks. In order to gain a more complete picture of the functioning of international capital markets, however, we hope that our research will be complemented in the future by similar examination of other market players' behavior.

\footnotetext{
${ }^{33}$ This point has been made by Calvo and Mendoza (1999). More generally, this question touches on one of the paradoxes of the efficient market hypothesis: if markets are efficient, it does not pay to gather information, but markets cannot be efficient if nobody bothers to gather information. See Grossman and Stiglitz (1980).
} 


\section{References}

BERG, A. and C. PATTILlO (1999). "Are Currency Crises Predictable? A Test," IMF Staff Papers 46, No.2.

BORENSZTEIN, E., and GELOS, R. G. (2003a). "A Panic-Prone Pack? The Behavior of Emerging Market Mutual Funds,” IMF Staff Papers 50, No.1.

BORENSZTEIN, E., and GELOS, R. G. (2003b). "Leaders and Followers: Emerging Market Fund Behavior During Tranquil and Turbulent Times," Emerging Markets Review 4, 25-38.

BRONER, F., LORENZONI, G., and SCHMUKLER, S. (2003). "Why do emerging markets borrow short term?" mimeo.

BROWN, K., HARLOW, W.V., and L.T. STARKS (1996). "Of Tournaments and Temptations: An Analysis of Managerial Incentives in the Mutual Fund Industry,” Journal of Finance 51, 85-110.

BUSSE, J.A. (2001). "Another Look at Mutual Fund Tournaments," Journal of Financial and Quantitative Analysis 36, 53-73.

CALVO, G., and MENDOZA, E. (1999). "Rational Contagion and the Globalization of Securities Markets," Journal of International Economics 51, 79-113.

CARAMAZZA, F., RICCI, L., and SALGADO, R. (2000). "Trade and Financial Contagion in Currency Crises," IMF Working Paper 00/55.

CHEVALIER, J., and G. ELLISON (1997). "Risk Taking by Mutual Funds as a Response to Incentives," Journal of Political Economy 105, 1167-1199.

CHEN, HSIU-LANG, and G. PENNACHI (2002). 'Does Prior Performance Affect a Mutual Fund's Choice of Risk? Theory and Further Empirical Evidence," mimeo, University of Illinois.

DANIEL, N. D., and WERMERS, R. (2000). "Risk-Taking Behavior by Mutual Fund Managers: Do Managers 'Walk Away' from the Tournament?” mimeo.

DISYATAT, P., and GELOS, R.G. (2001). "The Asset Allocation of Emerging Market Mutual Funds," IMF Working Paper 01/111.

FROOT, K., O'CONNELL, P., and SEASHOLES, M. (2001). "The Portfolio Flows of International Investors, I," Journal of Financial Economics 59, 151-193.

GELOS, R.G., and WEI, S. J. (2002). “Transparency and International Investor Behavior,” NBER Working Paper 9720.

GOLDSTEIN, I. and PAUZNER, A. (2001). "Contagion of Self-Fulfilling Financial Crises Due to Diversification of Investment Portfolios,” mimeo, Tel Aviv University. 
GROSSMAN, S.J. and STIGLITZ, J.E. (1980). "On the Impossibility of Informationally Efficient Markets," American Economic Review 70, 393-408.

HARRISON, J., and KREPS, D. (1978). "Speculative investor behavior in a stock market with heterogeneous expectations," Quarterly Journal of Economics 92, 323-36.

HERNANDEZ, L.F. and VALDEZ, R.O. (2001). "What Drives Contagion: Trade, Neighborhood, or Financial Links?” IMF Working Paper 01/29.

HONG, H., and STEIN, J. (2003). "Differences of opinion, short sales constraints, and market crashes," Review of Financial Studies 16, 487-525.

JOHNSON, S. BOONE, P., BREACH, A., and FRIEDMAN, E. (2000). "Corporate Governance in the Asian Financial Crisis," Journal of Financial Economics 58, 141-186.

KAMINSKY, G., LYONS, R., and SCHMUKLER, S. (2000). "Managers, Investors, and Crises: Mutual Fund Strategies in Emerging Markets," NBER Working Paper 7855.

KAMINSKY, G., and REINHART, C. (2000). “On Crises, Contagion, and Confusion,” Journal of International Economics 51, 145-168.

KAMINSKY, G., REINHART, C., and C.A. VEGH (2003). "The Unholy Trinity of Financial Contagion," Journal of Economic Perspectives, 17 (2).

KODRES, L., and PRITSKER, M. (2002). “A Rational Expectations Model of Financial Contagion," Journal of Finance 57, 769-799.

KOSKI, J. L. and PONTIFF, J. (1999). "How Are Derivatives Used? Evidence from the Mutual Fund Industry," Journal of Finance 54, 791-816.

KUMAR, M.S. and A. PERSAUD (2001). "Pure Contagion and Investors' Shifting Risk Appetite: Analytical Issues and Empirical Evidence," International Finance 5, 401-436.

KYLE, A., and XIONG, W. (2001). “Contagion as a Wealth Effect,” Journal of Finance 56, 14011440 .

SCHEINKMAN, J., and XIONG, W. (2003). "Overconfidence and speculative bubbles," Journal of Political Economy 111, 1183-219.

SCHINASI, G., and SMITH, T. (2000). "Portfolio Diversification, Leverage, and Financial Contagion," IMF Staff Papers 47, 159-176.

SIRRI, E.R. and TUFANO, P. (1998). "Costly Search and Mutual Fund Flows,” Journal of Finance 54, 359-375. 
VAN RIJCKEGHEM, C., and WEDER, B. (2001). "Sources of Contagion: Is it Finance or Trade?," Journal of International Economics 54, 293-308.

VAN RIJCKEGHEM, C., and WEDER, B. (2003). "Spillovers Through Banking Centers: A Panel Data Analysis of Bank Flows," Journal of International Money and Finance 22, 483-509.

WORLD BANK (2003). “Global Development Finance,” Washington, D.C.

YUAN, K. (2004). "Asymmetric Price Movements and Borrowing Constraints: A Rational Expectations Equilibrium Model of Crises, Contagion, and Confusion," Journal of Finance, forthcoming. 


\section{Appendix I: Fund performance and redemptions}

In the finance literature, the question of the relationship between past performance and risk taking by mutual funds has been studied repeatedly. Initial studies pointed to the presence of "gambling behavior" by fund managers who fall behind in their performance (see Brown, Harlow, and Starks, 1996, Chevalier and Ellison, 1997, and Sirri and Tufano, 1998). One reason for such behavior might be that fund managers' compensation rises with assets under management; if mutual funds with the best performance capture the lion's share of new inflows while funds that perform poorly are not penalized equally, this might create an incentive for managers to choose more risky portfolios if they are falling behind.

More recent studies, however, have questioned this hypothesis. Busse (2001) finds that mid-year losers decrease their risk during the second half of a calendar year; Koski and Pontiff (1999) report a positive correlation between current risk taking and past-year performance. Daniel and Wermers (2000) find that prior risk-taking behavior is a much better predictor than prior performance in explaining the future risk-taking behavior by fund managers. Chen and Pennachi (2002) argue that while fund managers do increase the fund's "tracking error" as its relative performance declines, this does not result in an increased variance of the fund's returns.

The incentives of dedicated emerging market funds have to our knowledge not yet been investigated in the literature, and a detailed analysis of this question is beyond the scope of this paper. One reason for this is that we do not have precise data about inflows, which we have to infer indirectly subtracting imputed fund gains from increases in reported size. A look at the data for global funds (Figure A1) however, does not suggest the presence of incentives to gamble: the nonparametrically estimated relationship between excess inflows in a given quarter and past year's excess inflows is positive, but not convex. 
Figure A1. Fund performance and inflows

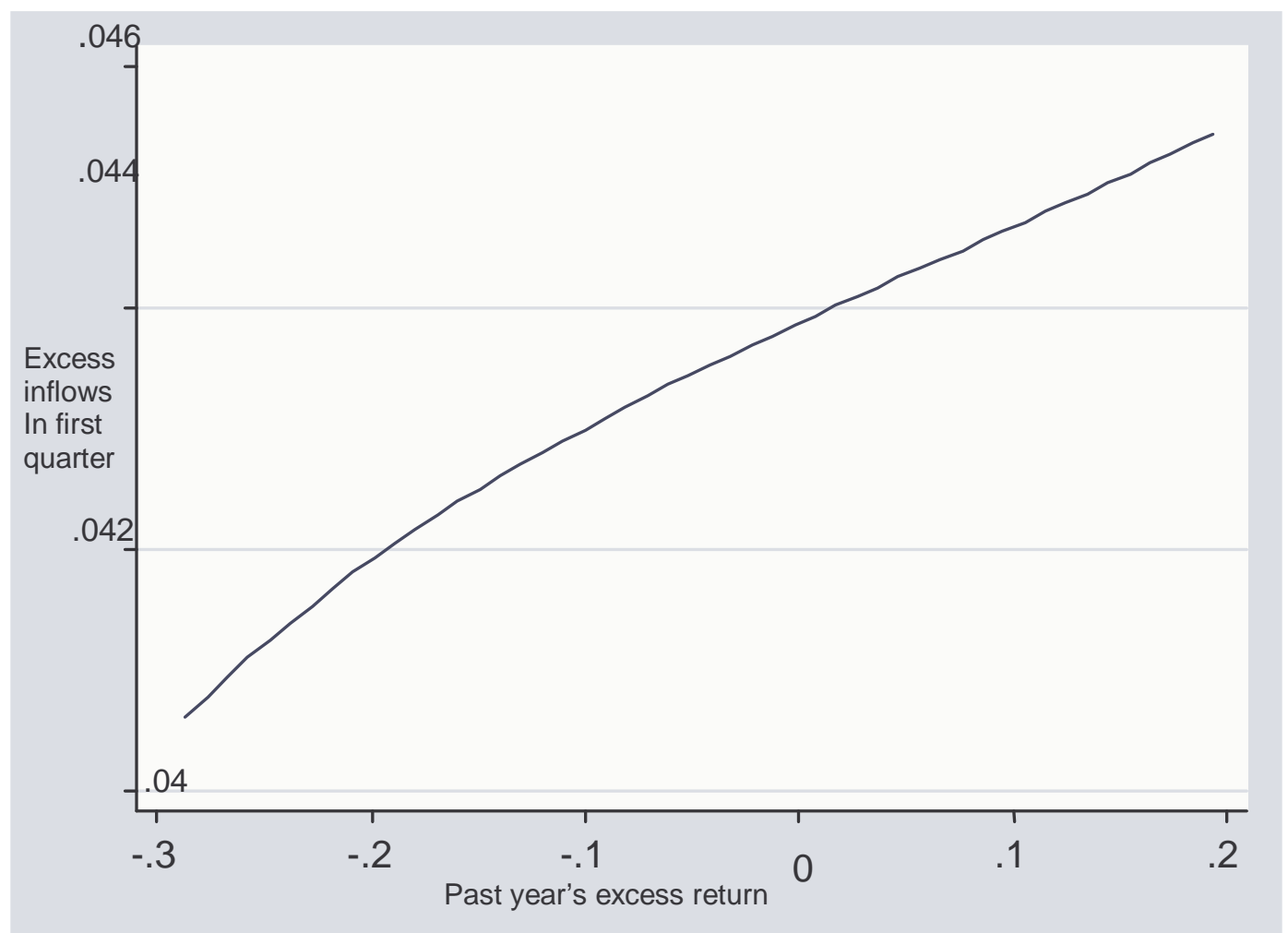

Note: Local polynomial regression of excess inflows (in excess of average inflows across funds) in the first quarter of a year on past year's excess return (in excess of average fund returns). The estimation uses an Epanechnikov kernel with a width of 0.3 . 


\section{Appendix II: Portfolio adjustment regressions with control variables}

Table A.1 shows the results of adding to our base regression changes in economic risk, financial risk, and political risk, both in levels and interacted with overexposure. The table shows that these variables do not have any effect on the estimates of the coefficient we had previously estimated. In addition, they are not statistically significant.

Table A.1: Portfolio adjustment (with control variables)

\begin{tabular}{|c|c|c|c|}
\hline & $\begin{array}{c}\text { Assuming } \\
\text { inelastic } \\
\text { supply }\end{array}$ & $\begin{array}{l}\text { Assuming } \\
\text { perfectly } \\
\text { elastic } \\
\text { supply }\end{array}$ & $\begin{array}{c}\text { No } \\
\text { assumption } \\
\text { on supply } \\
\text { elasticity }\end{array}$ \\
\hline adjustment term & - & - & $\begin{array}{l}0.427^{* *} \\
(0.007)\end{array}$ \\
\hline overexposure (t-1) & $\begin{array}{c}-0.044^{* * * *} \\
(0.002)\end{array}$ & $\begin{array}{c}-0.070^{* * * *} \\
(0.002)\end{array}$ & $\begin{array}{c}-0.061^{* * * *} \\
(0.002)\end{array}$ \\
\hline excess gains & $\begin{array}{l}3.415^{* * * *} \\
(0.237)\end{array}$ & $\begin{array}{c}-0.814^{* * * *} \\
(0.245)\end{array}$ & $\begin{array}{l}1.045^{* * *} \\
(0.235)\end{array}$ \\
\hline overexposure (t-1) & $0.665^{* * * *}$ & $1.023^{* * * *}$ & $0.872^{* * *}$ \\
\hline$\times$ excess gains & $(0.094)$ & $(0.095)$ & $(0.091)$ \\
\hline economic risk (t-1) & $\begin{array}{l}-0.005 \\
(0.004)\end{array}$ & $\begin{array}{l}0.014^{\text {***** }} \\
(0.004)\end{array}$ & $\begin{array}{l}0.006^{* * * *} \\
(0.004)\end{array}$ \\
\hline$\Delta$ financial risk $(\mathrm{t}-1)$ & $\begin{array}{l}-0.005 \\
(0.004)\end{array}$ & $\begin{array}{c}-0.009^{* * * *} \\
(0.004)\end{array}$ & $\begin{array}{c}-0.007^{* * *} \\
(0.004)\end{array}$ \\
\hline$\Delta$ political risk $(\mathrm{t}-1)$ & $\begin{array}{l}0.006^{* *} \\
(0.003)\end{array}$ & $\begin{array}{c}0.005 \\
(0.003)\end{array}$ & $\begin{array}{l}0.005^{* *} \\
(0.003)\end{array}$ \\
\hline overexposure (t-1) & -0.002 & 0.001 & -0.001 \\
\hline$\times \Delta$ economic risk $(\mathrm{t}-1)$ & $(0.002)$ & $(0.002)$ & $(0.002)$ \\
\hline overexposure (t-1) & $0.003^{*}$ & $0.007^{* * * *}$ & $0.006^{* * *}$ \\
\hline$\times \Delta$ financial risk $(\mathrm{t}-1)$ & $(0.002)$ & $(0.002)$ & $(0.002)$ \\
\hline overexposure (t-1) & 0.000 & -0.002 & -0.001 \\
\hline$\times \Delta$ political risk $(\mathrm{t}-1)$ & $(0.001)$ & $(0.001)$ & $(0.001)$ \\
\hline \# of observations & 39,691 & 37,174 & 37,174 \\
\hline$R^{2}$ & 0.02 & 0.03 & 0.11 \\
\hline
\end{tabular}

Notes: Dependent variable: change in country weight. One observation per fund-time-country. All variables normalized by beginning of period fund size. ${ }^{* * *},{ }^{* *}$, and ${ }^{*}$ means statistical significance at the $1 \%, 5 \%$, and $10 \%$ level respectively. $\Delta$ denote first differences. Economic, financial, and political risk refer to the International Country Risk Guide's (ICRG) monthly economic, financial, and political risk indices. 


\section{Appendix III: Equivalence of indices of interdependence}

We start from the first index of financial interdependence

$$
d_{c_{1}, c_{2}}=\sum_{i} r e_{c_{1}, i} \times o e_{i, c_{2}},
$$

where we have removed time sub-indices for simplicity. This expression can be rewritten as

$$
\begin{aligned}
d_{c_{1}, c_{2}} & =\sum_{i} \frac{a_{i, c_{1}}}{S \bar{b}_{c_{1}}}\left(\frac{a_{i, c_{2}}}{s_{i}}-\bar{b}_{c_{2}}\right)= \\
& =\frac{1}{S \bar{b}_{c_{1}}}\left(\sum_{i} s_{i} b_{i, c_{1}} b_{i, c_{2}}-S \bar{b}_{c_{1}} \bar{b}_{c_{2}}\right)= \\
& =\frac{1}{S \bar{b}_{c_{1}}}\left(\sum_{i} s_{i} b_{i, c_{1}} b_{i, c_{2}}-\sum_{i} s_{i} b_{i, c_{1}} \bar{b}_{c_{2}}-\sum_{i} s_{i} \bar{b}_{c_{1}} b_{i, c_{2}}+\sum_{i} s_{i} \bar{b}_{c_{1}} \bar{b}_{c_{2}}\right)= \\
& =\frac{1}{S \bar{b}_{c_{1}}} \sum_{i} s_{i}\left(b_{i, c_{1}}-\bar{b}_{c_{1}}\right)\left(b_{i, c_{2}}-\bar{b}_{c_{2}}\right)= \\
& =\sum_{i} \frac{s_{i}}{S} \frac{o e_{i, c_{1}}}{\bar{b}_{c_{1}}} o e_{i, c_{2}},
\end{aligned}
$$

where we have used $\sum_{i} a_{i, c_{1}}=S \bar{b}_{c_{1}}$ in the first equality; $a_{i, c_{1}}=s_{i} b_{i, c_{1}}, a_{i, c_{2}}=s_{i} b_{i, c_{2}}$, and $\sum_{i} a_{i, c_{1}}=S \bar{b}_{c_{1}}$ in the second equality; and $S \bar{b}_{c_{1}}=\sum_{i} s_{i} b_{i, c_{1}}, S \bar{b}_{c_{2}}=\sum_{i} s_{i} b_{i, c_{2}}$, and $S=\sum_{i} s_{i}$ in the third equality. 